\title{
Use of L1 in the Iranian EFL Classroom
}

\author{
Setareh Masoumi Mayni \\ Malaysia

\section{Shamala Paramasivam} \\ Associate Professor, Department of English, Universiti Putra Malaysia, Selangor, Malaysia \\ https://orcid.org/0000-0002-7213-9445
}

Manuscript ID:

EDU-2021-09023581

Volume: 9

Issue: 2

Month: March

Year: 2021

P-ISSN: 2320-2653

E-ISSN: 2582-1334

Received: 24.11.2021

Accepted: 08.02.2021

Published: 01.03.2021

Citation:

Mayni, Setareh Masoumi, and Shamala Paramasivam. "Use of L1 in the Iranian EFL Classroom.” Shanlax International Journal of Education, vol. 9, no. 2, 2021, pp. 34-45.

DOI:

https://doi.org/10.34293/ education.v9i2.3581

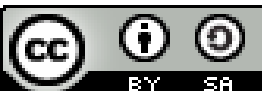

This work is licensed under a Creative Commons Attribution-ShareAlike 4.0 International License

\begin{abstract}
By reviewing the literature on the development of English language teaching methods in the last three decades, it is obvious that the idea of using the first language (L1) in the second language (L2) classroom has always been controversial. The history of language pedagogy and the role of the first language in foreign language learning generate debates in English as a foreign language. The teaching of English as a foreign language is growing every day in Iran, and as a result, the need for informing the best policy is getting more urgent. The principal intent of the current study, that investigates the use of L1 in the English classroom, is to determine teachers, students and policymakers' beliefs and attitudes towards the use of L1 in L2 classroom. The L1, in this case, is Farsi language and all the participants are native speakers of Farsi. One hundred and fifty students of the English Language Department at the elementary level at Tehran Institute of Technology are the participants of the study. They are all female and in their late teens or early twenties. The students and the teachers were surveyed by questionnaires and the researcher observed 10 classes and interviewed 3 teachers and 3 policymakers. The information gathered from the questionnaire was submitted to SPSS for analyzing the data, and the information gathered from the interview. Class observation check-list was used to triangulate the findings of the questionnaire. The results of this study indicate that teachers and students have different attitudes towards using L1 in the EFL classes. While students have a positive attitude, teachers have a negative attitude. The main reason mentioned by students for not being against the limited use of Farsi in their English class is that they believe using Farsi even in a limited sense can help them to understand difficult concepts. However, teachers believe in an English-only policy to be more exposed to the English language. Another finding of this study is that the functions of using Farsi by students or teachers in EFL classroom are: for explaining difficult parts, for managing the classroom, for explaining exam instructions, for explaining the two language differences, for checking comprehension, for seeking help from others, for joking with others, for making students relaxed and for presenting the meaning of new words. Given these findings, to match the student's and teachers '/policymakers' ideas about using L1 at the elementary level, an EFL teaching methodology that considers the use of Farsi, even in a limited way, is suggested.
\end{abstract}

Keywords: Language earning, L1 use in English class, Attitudes to L1 use in English class, EFL teaching and learning, Iranian EFL classroom, Codeswitching

\section{Background to the Study}

During the Grammar Translation Method era, using the first language has always been respected (Howatt \& Widdowson, 2004). However, right after World War I, there were several serious objections towards using L1 in L2 classes. The main problem was the absence of everyday spoken language in a real context. Since then, most popular English language teaching methods, including Communicative Language Teaching, tend to decrease the use of the L1 in L2 classrooms (Prodromou, 2003).

This view of avoiding learners' L1 has a significant impact on most modern L2 teaching materials, curriculum and syllabus (Cook, 2002). Using the mother tongue has been treated as a source of guilt, a taboo subject, and hint for teaching properly done only by weak teachers (Deller, 2003). Consequently, L2 only approach is viewed as an effective language teaching method (Atkinson, 1987). 
Apart from accepting the monolingual approach in ESL/EFL teaching, in recent years, there was a considerable shift in view among ELT experts. They argue that using learners' L1 has significant advantages (Deller, 2003). There are considerable studies that have investigated the use of L1 in the L2 classroom, and they have suggested that L1 can be a productive, facilitating, and mediating tool for teaching as well as learning (Rinvolucri, 2001).

There is psychological support to permit L1 in the L2 classroom. According to Schweers (1999), if a learner of a second language is asked to ignore his/ her mother tongue, he/she might feel his/her identity is threatened. Echevarria and Grave (2007) note that when students' mother tongue is welcomed in the L2 classroom, they feel their language is valued and respected. Nation (2001), quoted in Tang (2002), believes that the degradation of the mother tongue has a harmful psychological effect on learners. From a socio-cultural perspective, according to Kramsch (2000), the first language can facilitate the progress of the students' view towards the other culture. It is like a bridge designed to build interfaces among different cultures.

\section{Research Problem}

Research studies in this specific field have grown in number (Scheffler \& Domińska, 2018; Scheffler, et al. 2020). Researchers have focused on the amount and the frequency of using L1. In contrast, some have investigated the beliefs and attitudes of both teachers and learners towards the use of L1 in L2 classroom, and recently some (such as Scheffler \& Domińska (2018) and Scheffler, et al, (2020) have looked into its use on young preschool children. There has been attention paid to the use of various languages such as Spanish (Schweer, 1999), Chinese (Tang, 2002), Arabic (Machaal, 2012), Vietnamese (Kim Anh, 2010), and Turkish (Sali, 2014; Yatağanbaba \& Y1ldırım, 2015) to study the use of L1 in L2 classes, but there has been little research on the use of Farsi in EFL classroom. One study is conducted by Mahmoudi and Amirkhiz in March 2011 on "The use of Persian in the EFL classroom," which focused on the pre-university level of Iranian English learners. The other is "The Iranian EFL Students' and Teachers' Perception of Using Persian in General
English Classes," which was done by Hashemi and KhaliliSabet in December 2013, on dealing with L1 use, especially at the university level in Iran.

The teaching of English as a foreign language is growing every day in Iran, and as a result, the need for informing the best policy is getting more urgent. This study could be the first research which investigates the use of Farsi in EFL classroom that involves elementary students, teachers and policymakers and it uses a mixed-methods approach to study this phenomenon.

We believe L1 has been disfavored by all policymakers despite its multiple roles in facilitating the teaching and learning of L2. It is still not clear "Why is it so important to disregard the role of the students' L1 in the L2 classes?" This study examines whether forbidding L1 in L2 learning exists in the context of the use of Farsi language when teaching and learning English.

\section{Research Objectives}

As it has been mentioned in the background of the study, the use of students' L1 is beneficial in some ways for learning and teaching L2. From the literature considered in the problem statement, scant attention has been given to learners' L1 in L2 classes in Iran. Specifically, this study attempts to find answers to the following questions:

1. What is the attitude and belief of Iranian teachers and students towards using the Farsi language in EFL classes?

2. What are the reasons for their attitude?

3. What are the functions of students' and teachers' use of L1 in EFL classes?

\section{Related Literature \\ History of L1 in L2 Classes}

The history of using L1 in ESL classes indicates that there have been periodic but rather regular changes in different points of view on learners' L1 in the L2 classes (Auerbach, 1999). Classical Method was the only method by the end of the 19th century, under a new label, known as Grammar Translation Method. In this method, there is an emphasis on the syntax and the morphology of the target language (Hall, 2016). Learner's language plays the most important role in this method; L1 is the only medium 
of instruction and the only system of reference in second language acquisition (Stern, 1992).

Using the Grammar Translation Method resulted in the poor ability of students to speak English fluently, even after studying it for a long time. Therefore, opponents started to challenge this method for being a non-communicative method (Harmer, 2001) since this method had no contribution to enhancing the communication ability of students in the target language (Brown, 2000).

According to Cook (2001) in teaching methods such as CLT and Task-based Learning, using L1 is minimized and presenting authentic L2 is maximized. Krashen (1981) suggested comprehensible input, and he assumed that when learners are exposed to the massive amount of L2 and they have limited access to L1, they can acquire the second language more effectively (Tang, 2002). It can also lead to achieving language competence if opportunities for implicit and subconscious learning are provided. Other researchers believed that conscious and unconscious learning would be more activated by focusing on L2 and prohibiting L1. It is added that students can get the message even if they don't understand the precise meaning of the words and structures (AlNofaie, 2010). Thus, in most methods, the ideal classroom is a class with no use of L1 or with as little use as possible and omitting any reference to L1 was generally appreciated (Cook, 2001).

However, little by little, challenges were made against L1 use in second language learning classes. There has been a positive change toward translation and the use of L1 started to be seen as a communicative strategy which is helpful to be used and to be learned by learners (Gill, 2005). Subsequently, a new teaching method appeared, which allowed teachers to use L1 in L2 classes. This method was the New Concurrent Method that deliberately balanced the use of the two languages in class (Jacobson \& Faltis, 1990).

There are some other teaching methods in language teaching which have a positive attitude toward using L1 in L2 classes. Some of these methods are Reciprocal Language Teaching, Alternative Language Approach, The Two-way Immersion Model, and Dual Language Program (Hall, 2016). Among other approaches that actively assume a link between the first and the second language are: Dodson's Bilingual Method, Community Language Learning and The New Concurrent Method (Cook, 2001). Macaro (2009) formed a continuum for using L1 in language classes. "Optimal Position" is located at one end while "Virtual Position" is located at the other end. At "Optimal Position," L1 has no value and L1 use is discouraged. At "Virtual Position," L1 plays a major role and is encouraged in class. Between the two poles, we have L1 that plays a balanced role. However, there has been a movement towards an even-handed use of L1; this issue is debatable and arguable until now.

\section{Role of Mother Tongue in Language Classes}

According to Tang (2002) at the beginning and intermediate levels, teachers usually use the learners' mother tongue for explaining complicated ideas, word meanings and grammar points or for giving instructions. Teachers use L1 to clarify things when several attempts have already been made to communicate one idea in L2, but students are still confused. Here, L1 plays a supportive or facilitating role (Tang, 2002). According to Paramasivam (2009), using L1 can function as a communication strategy and a language learning strategy. When students use words from their L1 to express their intended meaning in the L2, the strategy is known as "language switch", where it functions as a communication strategy to convey the learners' message; as a language learning strategy, the language switch to L1 provides opportunities for learners to learn the L2 equivalent through the interlocutors or teachers. Cook (2001) believes that English language teachers use L1 to convey and check meanings of words or sentences, also, to explain grammar, to organize classes, to maintain discipline, to gain contact with individual students, and to test understanding.

\section{Methodology \\ Research Design}

The design of this research is a mixed-method approach to allow qualitative and quantitative data to be a complement of each other; it is based on triangulation. Therefore, questionnaires, class observation and interviews were employed to gather data. A mixed-method research design can be defined 
as a procedure to collect, analyze and mix both qualitative and quantitative methods in one study for a better understanding of the research problem (Creswell \& Poth, 2018).

\section{Data Site}

The Language Department of one of the famous institutions in Tehran is chosen. This institution, after years of experience in teaching the English language, is granting international language certificates and is cooperating with international educational organizations. It holds various educational courses, including English, French, German, and Italian language courses ranging from basic to advanced and preparation courses for international exams, such as IELTS, TOEFL iBT, ESOL.

\section{Subjects of the Study \\ Students}

150 students of the English Language Department at the Elementary level in a famous Institution located in Tehran are the participants of the study. They are all female and in their late teens or early twenties.

\section{Teachers}

10 English language instructors are another population of the study. They had to have more than 5 years of experience in this field and they had to have TTC, TEFL, or CELTA certificate. They were all teachers of the aforementioned institution. 3 teachers were selected for the interview among these 10 teachers.

\section{Policy Makers}

Three policymakers of the English Language Department of the Institution are other subjects of this study. These 3 policymakers were the head, a manager and a supervisor of the English Department of this institute.

\section{Data Collection}

Three tools were employed to collect data. These three tools are questionnaire, class observation, and interview.

\section{Questionnaire}

Two sets of questionnaires were used to collect information. These questionnaires were adapted from Machaal (2012). One of the questionnaires was designed for the students and the other was designed for the teachers. These questionnaires contain both close-ended and open-ended questions. Aside from yes/no questions and multiple choices, the openended questions seem useful because the participants could explain their choices or comment in details freely.

These questionnaires were used to elicit data about the student's and teachers' attitudes towards using Farsi language in the classroom and all other research questions of the study. The data gathered from the questionnaire is used to address all research questions of this study. All the questionnaires were administrated by the researcher to clarify any of the misunderstandings that they could have while the participants were completing them.

The first part of the questionnaire contains a Yes/ No question to get their main attitudes and beliefs. This Yes/ No question was followed by some multiple-choice questions to explain this attitude and to comment in detail.

The students' questionnaire was translated to Farsi and the students filled the Farsi version because their English level was not that good to understand all the questions and options.

The questionnaires were filled by the teachers and the teachers asked their students to fill the students' questionnaire for the extra 5 marks of their final marks. So, all the questionnaires were filled and returned.

\section{Class Observation}

Class observation can provide rich data for the researcher about the classroom interaction, behavior, and the amount of their conversation in L1 and L2 (Wallace, 1998).

The class observation was done by the researcher. The purpose of this observation was to investigate:

- The proportion of Farsi language to English.

- The amount of time that will be devoted to any of these languages.

- The occasions which teachers or students use Farsi language. 
The researcher observed 10 different classes, all at the Elementary level with 10 different teachers. The researcher used a checklist to notice all items correctly. This checklist was adapted from Machaal (2012). The only change that the researcher made was changing the word "Arabic" to the word "Farsi."

For a closer analysis or any future references, the whole class was observed and any of the useful information (action or behavior) was noted by the observer. Each of the classes took 1 hour and a half with a quarterback.

Checklists, together with filled notes, were used to address research questions 2 and the reasons for using L1, frequency and communicative functions.

Teachers and Students are not informed about the objective of the research. They just know that the researcher is doing the observation for a research purpose. The aim is to avoid any sensitization or temptation to have different behavior from their usual behavior because what the researcher wants is to observe and gather data from an authentic classroom.

\section{Interview}

Ten semi-structured interview questions were prepared for teachers and 7 semi-instructed interview questions were prepared for policymakers to ask from policymakers to gather relevant data. Semistructured questions are preferred because it gives more freedom to the interviewees to better express their beliefs and ideas. All the interview questions were adapted from Machaal (2012). His work was on the same objective and questions, but he has worked on the Arabic language. The only alternation which was done by the researcher was changing the word "Arabic" to the word "Farsi."

The interviews were conducted after observing the classes and administrating the questionnaires and collecting them back.

From the 10 teachers who completed the questionnaires, three were interviewed by the researcher. They were randomly selected for the interview. All three policymakers were interviewed by the researcher too.

\section{Data Analysis}

The questionnaire, class observation, and interview are the 3 tools used to gather data. After collecting the data, they were analyzed as follows:

The information gathered from the questionnaires was submitted to the computer software relevant for analyzing the data quantitatively. The software used for analyzing the data was SPSS. The data gathered from the questionnaires were converted to a percentage. Percentage value was chosen because it is easier to compare the results.

For the class observation data, a class observation checklist was used to summarize the role of the English language in each of the classes. The checklists, together with notes provided by the observer, were summarized.

The information gathered from the interviews and observation check-lists was used to triangulate the findings of the questionnaires with regards to all research questions. The quantitative data analyses could help the researcher to gather the participants' beliefs and attitudes by a numerical representation. The qualitative analysis also could help to get further details of these beliefs and attitudes.

\section{Findings}

RQ1: Attitude and belief of Iranian teachers and students towards using the Farsi language in EFL classes

As it is shown in Figure 1, 55\% of the student had a positive attitude towards using L1 in their EFL classes and $45 \%$ of the students had a negative attitude towards using L1 in the L2 classroom.

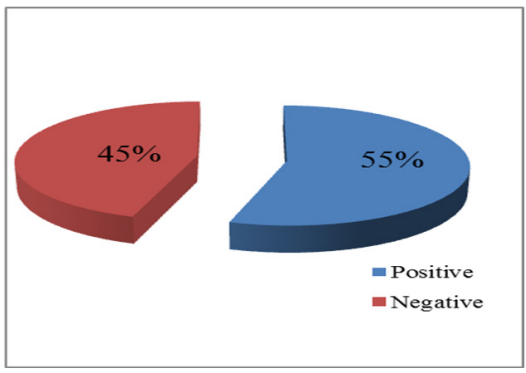

\section{Figure 1: Students' Main Attitude towards} Using L1

As it is seen in Figure 2, 40\% of the teachers had a positive attitude towards using L1 in their EFL classes and $60 \%$ of the teachers had a negative attitude towards using L1 in L2 classroom. 


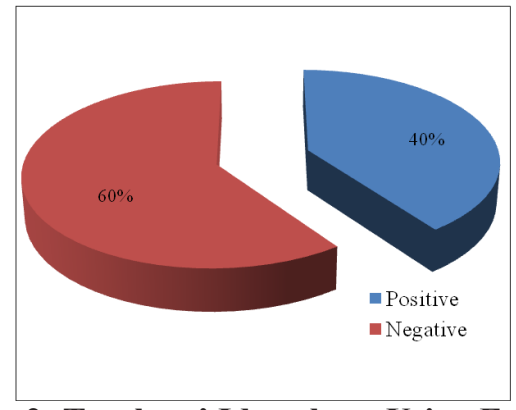

Figure 2: Teachers' Idea about Using Farsi in the EFL Classroom

As in Figure 3, the options " $\mathrm{C}$ " and " $\mathrm{D}$ " of this question have the most percentage and option " $\mathrm{A}$ " has the least percentage. The overall analysis of this question answers shows that in the teachers' idea, Farsi can help the students.

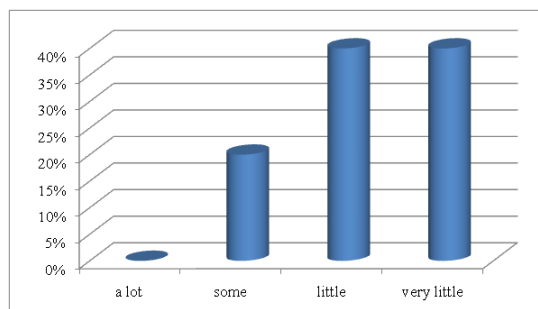

Figure 3: Teachers' view about the Amount of

\section{L1 that Helps Students}

From Fig. 4, option "B" of this question has the most percentage and option " $\mathrm{A}$ " has least percentage. The overall analysis of this question answers shows that in the teacher's idea, it is not extremely difficult for students if they use only English.

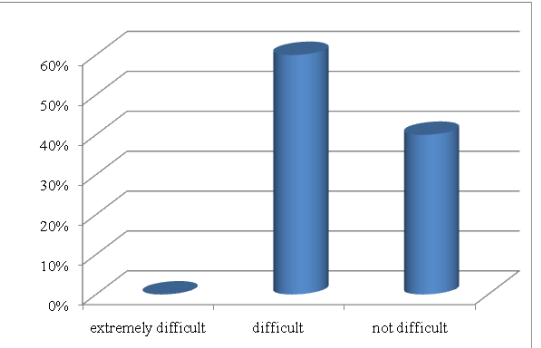

Figure 4: Teachers' Idea about the Difficulty of Students' Understanding if they use only English

As in Figure 5, the option " $\mathrm{D}$ " of this question has the most percentage. The options "A" and "B" have the least percentage. The overall analysis of this question answers shows that in the teachers' idea, the amount of their current use of Farsi language is generally little.

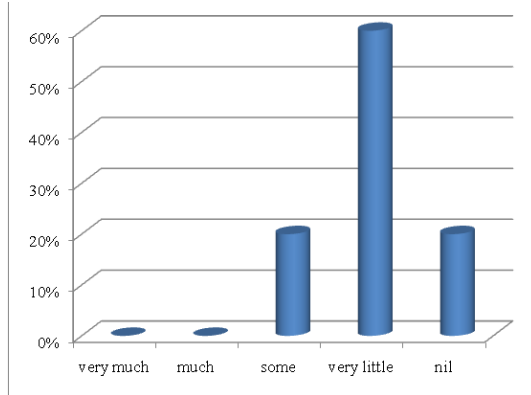

Figure 5: Teachers' Idea about their Current Use of Farsi in EFL Classroom

As seen in Figure 6, the option " $\mathrm{B}$ " of this question is $100 \%$. The option " $\mathrm{A}$ " is $0 \%$. The overall analysis of this question answers shows that in the teachers' idea their current books do not encourage students and teachers to use L1.

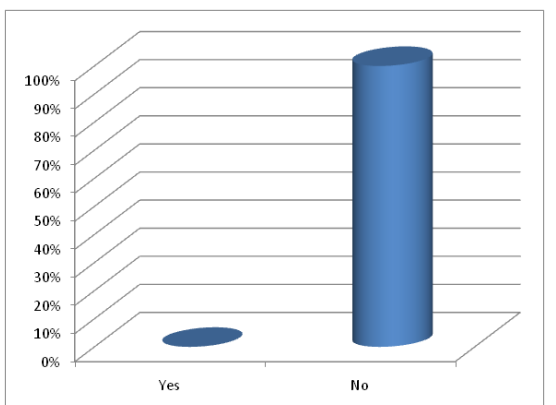

Figure 6: Teachers' Answer about any Encouragements of the Course Book for Using Farsi

As understood in Figure 7, the option " $A$ " of this question has the most percentage (70\%) the option " $\mathrm{B}$ " is $30 \%$ and options " $\mathrm{C}$," "D" and "E" have zero percentage. The overall analysis of this question answers shows that in the teachers' idea, generally, students are not allowed to speak in Farsi for more than $15 \%$ of their class duration.

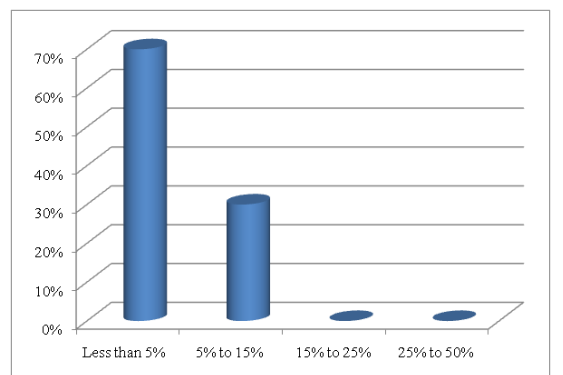

Figure 7: Teachers' Idea about the Percentage of Farsi in their Class 
Students' Attitude toward using L1 in EFL Classroom

From the data gathered, it can be concluded that Iranian EFL learners at the elementary level believe that using L1 is effective and important. They have mainly a positive attitude towards the use of their mother tongue in the English class. This study demonstrates that most of the students at the elementary level are willing to use Farsi and this outcome is by the findings of the studies done by Hashemi and KhaliliSabet (2013), Machaal (2012) and Al-Nofaie (2010).

The findings of this study stand in contrast with the findings of a study by Leila Mahmoudi (2011). She found that EFL learners support English domination in their EFL classes and are critical of using L1 excessively. Also, the findings are in line with some other researches like Nation (2001), Harbord (1992), and Atkinson (1987) about this assumption that using L1 by learners is a natural phenomenon.

\section{Teachers' Attitude towards using L1 in EFL Classroom}

In contrast with the students' view, most Iranian EFL teachers do not have such a positive attitude towards using the Farsi language in their English classes. They assert that the English-only policy will enhance the students' exposure to English, although they believe that if they use only English, it would not be easy for their students to understand. Their use of L1 depends on their students' needs most of the time.

RQ2: Reasons for Students and Teachers Attitudes towards using L1 in EFL Classroom Students' Reasons for using Farsi

As in Figure 8, most of the respondents who had a positive attitude towards using L1 (47\%) mentioned "to understand difficult concepts" as the main reason to use L1 in the EFL classrooms. "To feel relax, at ease, comfortable and to have less stress" is another reason mentioned by $13 \%$ of the respondents.

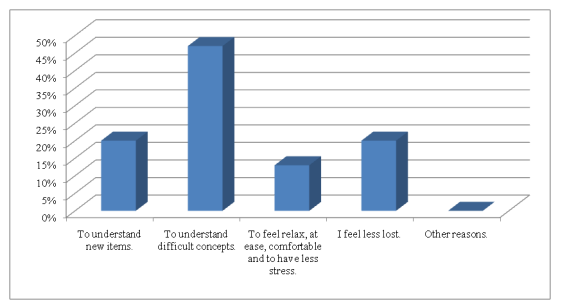

Figure 8: Percentage of Each Item for "Yes" Answers

\section{Students' Reasons for not Using Farsi}

Those who had a negative attitude towards using L1 in their EFL classes were asked why the Farsi language should not be used in the English classroom. As shown in Figure 9, most of the respondents who had a negative attitude towards using L1 (28\%) mentioned "to avoid bad learning habits" as the main reason not to use L1 in EFL classrooms. "To enhance exposure to English" is another reason, as it is mentioned by $15 \%$ of the respondents.

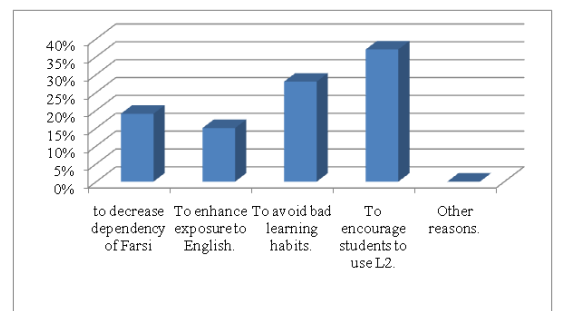

\section{Figure 9: Percentage of Each Item for "No" Answers}

\section{Teachers' Reasons for Using Farsi}

Those who had a positive attitude towards using L1 in their EFL classes were asked why using the Farsi language is important in the English classroom. As it is shown in Figure 10, most of the respondents (75\%) mentioned that using L1 "helps students' comprehension of English" in EFL classroom and 25 of the respondents believed that using L1 is "less time-consuming."

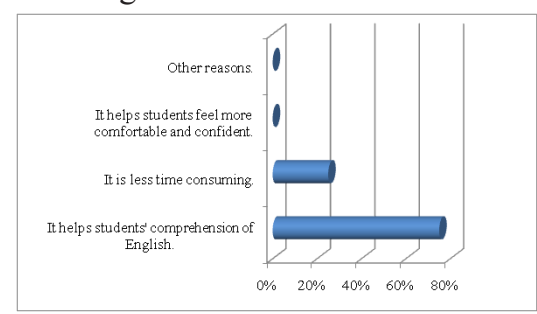

Figure 10: Percentage of Each Item for "Yes" Answers 
Teachers' Reasons for not Using Farsi

Those teachers who had a negative attitude towards using L1 in their EFL classes were asked why Farsi Language shouldn't be used in English classrooms. As it is shown in Figure 11, most of the respondents who had a negative attitude toward using L1 (66\%) mentioned "to enhance exposure to English." As the main reason not to use L1 in the EFL classroom. "To decrease dependency on Farsi" is another reason mentioned by $33 \%$ of the respondents.

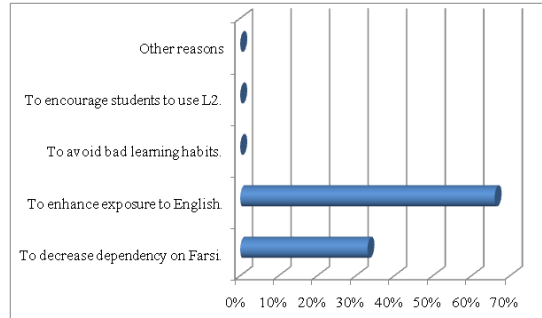

Figure 11: Percentage of Each Item for "No" Answers

As presented in Figure 12, the option "E" of this question has the most percentage $(50 \%)$ the option " $\mathrm{C}$ " is $40 \%$, the option " $\mathrm{B}$ " is $10 \%$, and the and options "A," "D" and " $F$ " have zero percentage. The overall analysis of this question answers shows that in the teachers' idea, the students may use Farsi to use bilingual dictionaries and translate words to show that they understood it. Only one of the teachers mentioned "to ask and answer the question" as one of the purposes for using Farsi in the English classroom.

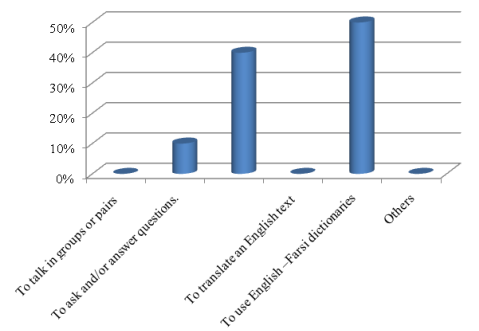

Figure 12: The Purposes of Using L1 by Students in Teachers' Idea

As seen in Figure 13, option " $\mathrm{B}$ " of this question has the most percentage $(70 \%)$ the option " $\mathrm{A}$ " is $30 \%$, and options " $C$ " and " $\mathrm{D}$ " have zero percentage. The overall analysis of this question answers shows that in the teachers' idea if students do not use Farsi, it is not because they do not want it, the reason is that they discouraged the tendency or the textbooks and the teachers' book do not encourage the tendency.

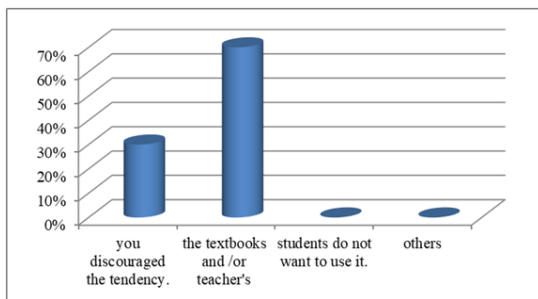

Figure 13: Teachers' Idea about Reasons to Use L1

As in Figure 14, the option " $A$ " of this question has the most percentage (70\%) the option " $\mathrm{B}$ " is $30 \%$, and options " $C$," "D", and "E" have zero percentage. The overall analysis of this question answers shows that in the teachers' idea, generally, students are not allowed to speak in Farsi for more than 15\% of their class duration.

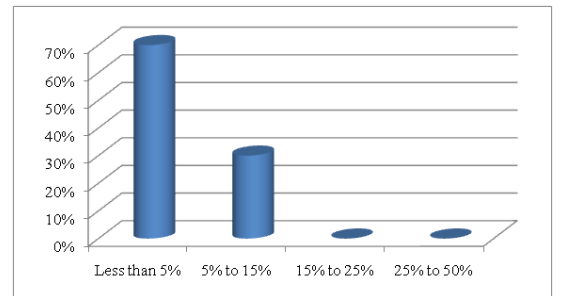

Figure 14: Teachers' Idea about the Percentage of Farsi in Their Class

\section{RQ3: Functions of using L1}

As in Figure 15, the option " $C$ " of this question has the most percentage, and option " $\mathrm{A}$ " has the least percentage. The overall analysis of this question answers shows that the students' idea for managing the EFL classroom using L1 is not very necessary.

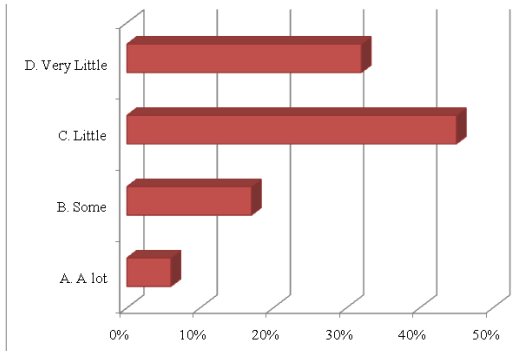

Figure 15: Students' Idea about the Amount of L1 to Manage the Classroom 
As in Figure 16, option " $A$ " of this question has the most percentage, and option " $\mathrm{C}$ " has the least percentage. The overall analysis of this question answers shows that in the students' idea for explaining difficult parts, L1 should be used.

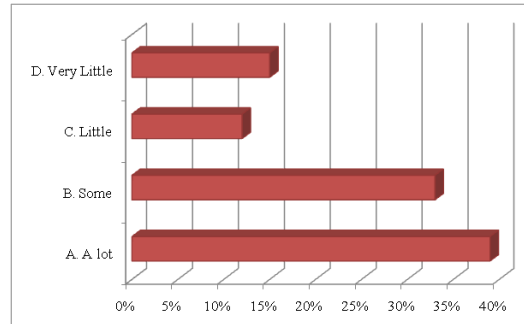

Figure 16: Students' Idea about the Amount of

\section{L1 to Explain Difficult Parts}

As seen in Figure 17, the option " $D$ " of this question has the most percentage and option " $\mathrm{A}$ " has the least percentage. The overall analysis of this question answers shows that in the students' idea, using L1 for explaining exam instructions has an average status.

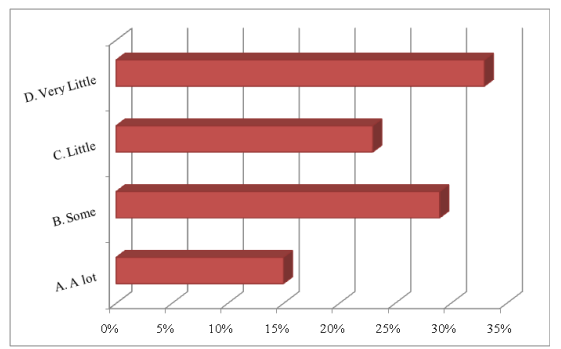

Figure 17: Students' Idea about the Amount of

\section{L1 to Explain Exam Instructions}

As presented in Figure 18, option " $\mathrm{C}$ " of this question has the most percentage, and option "A" has the least percentage. The overall analysis of this question answers shows that in the students' idea, using L1 is not very necessary for explaining the two language differences.

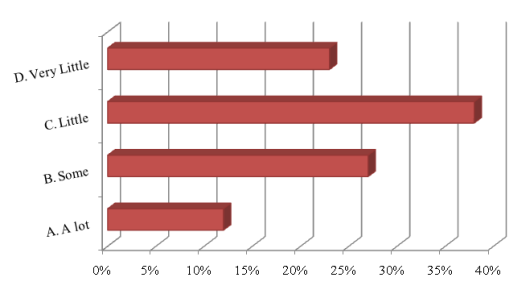

Figure 18: Students' Idea about the Amount of L1 to Explain the Two Language Differences
As in Figure 19, option "B" of this question has the most percentage, and option " $\mathrm{A}$ " has the least percentage. The overall analysis of this question answers shows that in the students' idea, using L1 for checking comprehension has an average status.

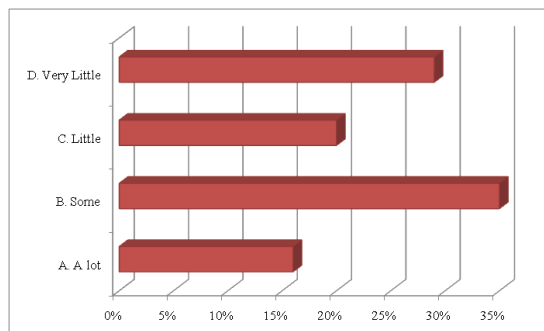

Figure 19: Students' Idea about the Amount of

\section{L1 to Check Comprehension}

As seen in Figure 20, the option " $D$ " of this question has the most percentage, and option " $\mathrm{A}$ " has the least percentage. The overall analysis of this question answers shows that in the students' idea, using L1 is not that necessary for seeking help from others.

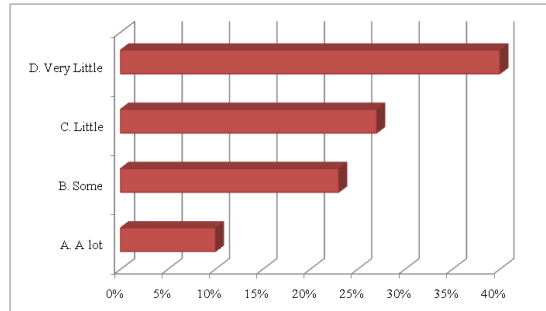

Figure 20: Students' Idea about the Amount of

\section{L1 to Seek Help from Others}

As presented in Figure 21, the option " $D$ " of this question has the most percentage and option "A" has the least percentage. The overall analysis of this question answers shows that in the students' idea for joking with others, teachers and students can use L1 but limitedly.

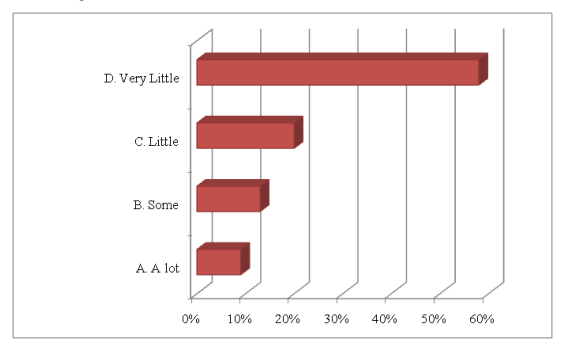

Figure 21: Students' Idea about the Amount of L1 to Joke with Others 
As shown in Figure 22, the option " $\mathrm{D}$ " of this question has the most percentage and option " $\mathrm{A}$ " has the least percentage. The overall analysis of this question answers shows that in the students' idea using L1 for making students relaxed is not necessary.

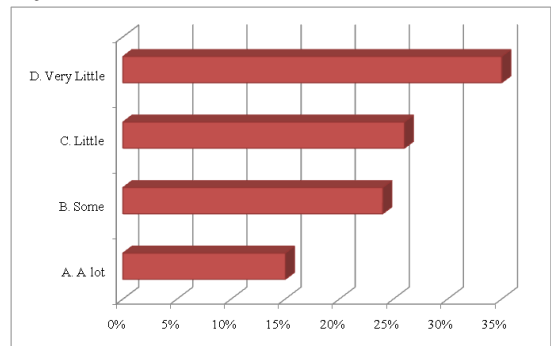

Figure 22: Students' Idea about the Amount of

\section{L1 to Make Students Relaxed}

As in Figure 23, the options " $A$ " and " $C$ " of this question have the most percentage and option " $\mathrm{B}$ " has the least percentage. The overall analysis of this question answers show that students have completely different ideas about using L1 for presenting new words' meaning.

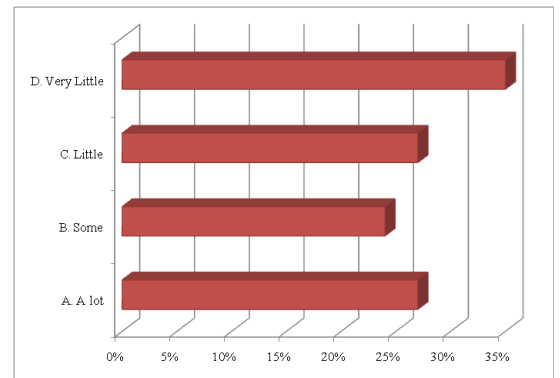

Figure 23: Students' Idea about the Amount of L1 to Present Meaning of New Words

\section{Discussion and Summary of Findings}

The outcome of this study indicates that the majority of Iranian EFL learners have a positive attitude towards the use of Farsi language at the elementary level and they agree that EFL teachers' limited use of Farsi language can assist the students' learning of English, especially in helping them to understand difficult concepts.

The functions of using Farsi by students or teachers in EFL classroom are: for explaining difficult parts, for managing the classroom, for explaining exam instructions, for explaining the language differences between L1 and L2, for checking comprehension, for seeking help from others, for joking with others, for making students relaxed and for presenting the meaning of new words.

The study also revealed that the majority of the teachers believe in the English-only policy. They believe their students should be exposed only to the English language, and their main attitude toward using L1 in class is negative. However, they believe that in certain situations, learners and teachers may use Farsi, such as when consulting English-Farsi dictionaries, translating English words into Farsi language to show that learners understand the words, and for asking or answering questions. Observations revealed that teachers did not use Farsi for more than $15 \%$ of the class duration. Most of the classes ran with less than $5 \%$ of using Farsi language. This is also because of the rule that forbids students and teachers from using the L1. Policymakers too, do not advise teachers and students to use Farsi in their classes because they generally believe that using L1 hinders L2 learning.

It is worth mentioning that teachers and language policymakers should deliberate on L1 use in L2 learning carefully; limited but constructive use of L1 in L2 use could be seriously considered.

\section{Concluding Remarks}

In a context like Iran, English is a foreign language. Due to this fact rejecting the role of L1 in learning English may not work. Using Farsi in a limited and constructive manner is believed to play a useful role in the EFL classroom. Therefore, for Iranian EFL students, especially at the elementary level, a practical methodology needs to consider the use of Farsi as a mediating teaching-learning tool.

\section{References}

Al-Nofaie, Hafia. "The Attitudes of Teachers and Students towards using Arabic in EFL Classrooms in Saudi Public Schools: A Case Study." Novitas Royal Research on Youth and Language, vol. 4, no. 1, 2010, pp. 64-95.

Atkinson, David. "The Mother Tongue in the Classroom: A Neglected Resource?" ELT Journal, vol. 41, no. 4, 1987, pp. 241-247.

Auerbach, Elsa. "The Power of Writing, the Writing of Power: Approaches to Adult ESOL Writing Instruction." Focus on Basics, vol. 3, 1999. 
Brown, H. Douglas. Principles of Language Teaching and Learning. Longman, 2000.

Brown, H. Douglas. Teaching by Principles: An Interactive Approach to Language Pedagogy. Pearson Education, 2007.

Cook, Vivian. "Background to the L2 User." Portraits of the L2 User, Multilingual Matters, 2002, pp. 1-28.

Cook, Vivian. "Using the First Language in the Classroom." Canadian Modern Language Review, vol. 57, no. 3, 2001, pp. 402-423.

Creswell, John W., and Cheryl N. Poth. Qualitative Inquiry \& Research Design: Choosing among Five Approaches. Sage Publications, 2017.

Echevarria, Jana, and Anne Graves. Sheltered Content Instruction: Teaching EnglishLanguage Learners with Diverse Abilities. Pearson, 2006.

Gill, Saran Kaur. "Language Policy in Malaysia: Reversing Direction." Language Policy, vol. 4, 2005, pp. 241-260.

Hall, Graham. "Method, Methods and Methodology: Historical Trends and Current Debates." The Routledge Handbook of English Language Teaching. Routledge, 2016.

Harbord, John. "The Use of the Mother Tongue in the Classroom." ELT Journal, vol. 46, no. 4, 1992, pp. 350-355.

Harmer, Jeremy. The Practice of English Language Teaching. Pearson, 2001.

Hashemi, Seyed M., and Masoud Khalili Sabet. "The Iranian EFL Students' and Teachers' Perception of Using Persian in General English Classes." International Journal of Applied Linguistics and English Literature, vol. 2, no. 2, 2013, pp. 142-152.

Howatt, A. P. R., and H.G. Widdowson. A History of English Language Teaching. Oxford University Press, 2004.

Jacobson, Radolfo, and Christian Faltis. Language Distribution Issues in Bilingual Schooling. Multilingual Matters, 1990.

Kabir, Tamanna Sharmin. “Teachers' and Students' Perception of Using Translation (L1) for Developing Reading Skill." Shanlax Internatioanl Journal of English, vol. 8, no. 4, 2020, pp. 1-11.
Kramsch, Claire. "Second Language Acquisition, Applied Linguistics, and the Teaching of Foreign Languages." The Modern Language Journal, vol. 84, no. 3, 2000, pp. 311-326.

Krashen, Stephen D. Second Language Acquisition and Second Language Learning. Pergamon Press, 1981.

Macaro, Ernesto. "Teacher Use of Code switching in the Second Language Classroom: Exploring 'Optimal' Use." First Language Use in Second and Foreign Language Learning. Multilingual Matters, 2009, pp. 35-49.

Machaal, Brahmin. "The Use of Arabic in English Classes: A Teaching Support or a Learning Hindrance?" Arab World English Journal, vol. 3, no. 2, 2012, pp. 194-232.

Mahmoudi, Leila, and Seyed Yasin Yazdi Amirkhiz. "The Use of Persian in the EFL ClassroomThe Case of English Teaching and Learning at Pre-University Level in Iran." English Language Teaching, vol. 4, no. 1, 2011, pp. $135-140$

Nation, I.S.P. Learning Vocabulary in Another Language. Cambridge University Press, 2001.

Paramasivam, Shamala. "Language Transfer as a Communication Strategy and a Language Learning Strategy in a Malaysian ESL Classroom." Asian EFL Journal, vol. 11, no. 1, 2009, pp. 192-229.

Pinter, Annamaria. Teaching Young Language Learners. Oxford University Press, 2017.

Prodromou, K. "In Search of the Successful User of English: How a Corpus of Non-native Speaker Language could Impact on EFL Teaching." Modern English Teacher, vol. 12, no. 2, 2003.

Rao, Parupalli Srinivas. "The Effective Use of Authentic Materials in the English Language Classrooms." Shanlax International Journal of Arts, Science and Humanities, vol. 7, no. 1, 2019, pp. 1-8.

Rinvolucri, M. "Mother Tongue in the Foreign Language Classroom: Why and How?" Modern English Teacher, vol. 10, no. 2, 2001, pp. 41-44.

Sali, Pinar. "An Analysis of the Teachers' Use of L1 in Turkish EFL classrooms." System, vol. 42, 2014, pp. 308-318. 
Scheffler, Pawel, and Anna Domińska. "Own- Stern, H.H. Issues and Options in Language Language Use in Teaching English to Teaching. Oxford University Press, 1992. Preschool Children." ELT Journal, vol. 72, no. 4, 2018, pp. 374-383.

Scheffler, Pawel, et al. "The Peppa Pig Television Series as Input in Pre-Primary EFL Instruction: A Corpus-based Study." International Journal of Applied Linguistics, 2020.

Schweers, C. "Using L1 in the L2 Classroom." English Teaching Forum, vol. 37, 1999, pp. 6-13.

Tang, Jinlan. "Using L1 in the English Classroom." English Teaching Forum, vol. 40, 2002, pp. 36-43.

Wallace, Michael J. Action Research for Language Teachers. Cambridge University Press, 1998. Yatağanbaba, Esra, and Rana Yıldırım. "EFL Teachers' Code Switching in Turkish Secondary EFL Young Language Learner Classrooms." International Journal of Linguistics, vol. 7, no. 1, 2015, pp. 82-101.

\section{Author Details}

Setareh Masoumi Mayni, Malaysia, Email ID: masoumi.setareh@gmail.com

Shamala Paramasivam, Associate Professor, Department of English, Universiti Putra Malaysia, Selangor, Malaysia, Email ID: shamala@upm.edu.my 